\title{
Effects of relative plate motion on the deep structure and penetration depth of slabs below the Izu-Bonin and Mariana island arcs
}

\author{
Rob van der Hilst ${ }^{a}$, Tetsuzo Seno ${ }^{b}$ \\ ${ }^{a}$ Research School of Earth Sciences, Institute of Advanced Studies, The Australian National University, Canberra, ACT 0200, Australia \\ ${ }^{b}$ Earthquake Research Institute, University of Tokyo, Tokyo 113, Japan
}

(Received May 21, 1993; revised and accepted October 7, 1993)

\begin{abstract}
An increasing number of seismological studies indicate that slabs of subducted lithosphere penetrate the Earth's lower mantle below some island ares but are deflected, or, rather, laid down, in the transition zone below others. Recent numerical simulations of mantle flow also advocate a hybrid form of mantle convection, with intermittent layering. We present a multi-disciplinary analysis of slab morphology and mantle dynamics in which we account explicitly for the history of subduction below specific island arcs in an attempt to understand what controls lateral variations in slab morphology and penetration depth. Central in our discussion are the Izu-Bonin and Mariana subduction zones. We argue that the differences in the tectonic evolution of these subduction zones-in particular the amount and rate of trench migration - can explain why the slab of subducted oceanic lithosphere seems to be (at least temporarily) stagnant in the Earth's transition zone below the Izu-Bonin arc but penetrates into the lower mantle below the Mariana arc. We briefly speculate on the applicability of our model of the temporal and spatial evolution of slab morphology to other subduction zones. Although further investigation is necessary, our tentative model shows the potential for interpreting seismic images of slab structure by accounting for the plate-tectonic history of the subduction zones involved. We therefore hope that the ideas outlined here will stimulate and direct new research initiatives.
\end{abstract}

\section{Introduction}

One of the challenges in earth sciences is to understand the dynamic behaviour of the Earth's mantle, including the convective system related to the motion of lithospheric plates at the Earth's surface. Particularly enigmatic has been the scale length of convective flow: is convection in the

[UC] upper mantle and transition zone separate from that in the lower mantle ("layered convection") or do convection cells encompass the entire mantle ("whole mantle convection")? Central in the discussion has been whether or not slabs of former oceanic lithosphere penetrate the boundary between the Earth's transition zone (410-660 km) and the lower mantle $(660-2900 \mathrm{~km})$ [1-5].

Inversions of travel times of seismic waves have provided images of subducted slab below northwestern Pacific island arcs that are inconsis- 
tent with either layered convection or whole mantle flow with unobstructed slab penetration [6-9]. Tomographic images suggest that subducted slabs continue to lower mantle depths below some island arcs but are laid down in the transition zone below others, and that the boundary between the transition zone and lower mantle acts as a strong though imperfect barrier for mantle flow. This is in accord with mounting evidence from numerical fluid dynamical modelling for a hybrid form of mantle convection, perhaps with a predominance of layering [10,11]. Despite an increasing concurrence on the mode and large-scale structure of convection, rapid lateral variations in slab morphology and the behaviour of individual slabs are still poorly understood. Available tectonic reconstructions of individual subduction zones could provide independent information about slab structure, but are, unfortunately, only rarely used to interpret seismic observations.

Results of tomographic imaging by Van der Hilst and co-workers $[7,8]$ indicate that subducted slab is trapped in the Earth's transition zone below marginal basins in the back-arc realms of the (southern) Kuril, Japan, and Izu-Bonin arcs. In contrast, slabs of subducted lithosphere seem to penetrate into the lower mantle below the Sea of Okhotsk, and below the Mariana arc. Van der Hilst and co-workers $[7,8]$ speculated that these lateral variations in slab morphology can be understood by combining plate-tectonic reconstructions with concepts from fluid dynamical modelling and petrochemistry. In the present paper we elaborate their suggestion. We reconcile inferences from several earth-scientific disciplines and show in a qualitative way how seismic and platemotion data can be combined explicitly.

We use the spatial and temporal evolution of the morphology of the subducted Pacific plate below Izu-Bonin and Mariana arcs as an example, but comment on other subduction zones as well. By outlining differences in the tectonic evolution of these ares we aim to understand why the slab is trapped in the transition zone below the former but penetrates the " $660 \mathrm{~km}$ " discontinuity below the latter. We show that the term "deflection", although often used, is not an adequate description of the predominant physical process that leads to, e.g., the Izu-Bonin type slab profile.

We first discuss seismic evidence pertaining to the lateral variation in slab morphology below the Izu-Bonin and Mariana arcs. Subsequently, we review briefly some relevant concepts from fluid dynamics and petrochemistry, and outline a model for the plate-tectonic reconstruction of the area under study. Finally, we combine this information into a hybrid model for the evolution of the morphology of the Izu-Bonin and Mariana subduction zones.

\section{Lateral variations in shape of seismic zones and subducted slabs}

Old lithosphere of the Pacific plate subducts below the Philippine Sea (PHS) plate at the IzuBonin and Mariana trenches, with a rate of convergence that decreases towards the south [12] (Fig. 1). Both the shape of the seismic WadatiBenioff zones $[13,14]$ and the nature of subduction-related seismicity changes dramatically from north to south [15-17]. In Fig. 2 we delineate the seismic zones below the Izu-Bonin and Mariana arcs in a simple way by projecting earthquake hypocentres to vertical section planes. We used hypocentres from Engdahl, Van der Hilst, and Buland (in prep.). As can be seen in Fig. 2, the Wadati-Benioff zone has a shallow dip at $35^{\circ} \mathrm{N}$ (and below Japan); near $28^{\circ} \mathrm{N}$ it is distorted and its dip changes to sub-horizontal at a depth of about $500 \mathrm{~km}$; between $25^{\circ} \mathrm{N}$ and $21^{\circ} \mathrm{N}$ very few earthquakes occur below a depth of $300 \mathrm{~km}$; and south of $19^{\circ} \mathrm{N}$ the Mariana seismic zone is nearvertical with the deepest earthquakes significantly deeper than below the Izu-Bonin arc. Southward from Honshu, Japan, the seismic coupling between subducting and overriding plates decreases and the Mariana subduction zone is almost "decoupled" [15-17]. Below the Izu-Bonin arc the complexity of deformation within the slab increases in the same direction [14,18]: events representing shear failure indicate the lateral, southward movement of the deeper part of the slab. In contrast, focal mechanism solutions of deep earthquakes below the Mariana arc suggest the 


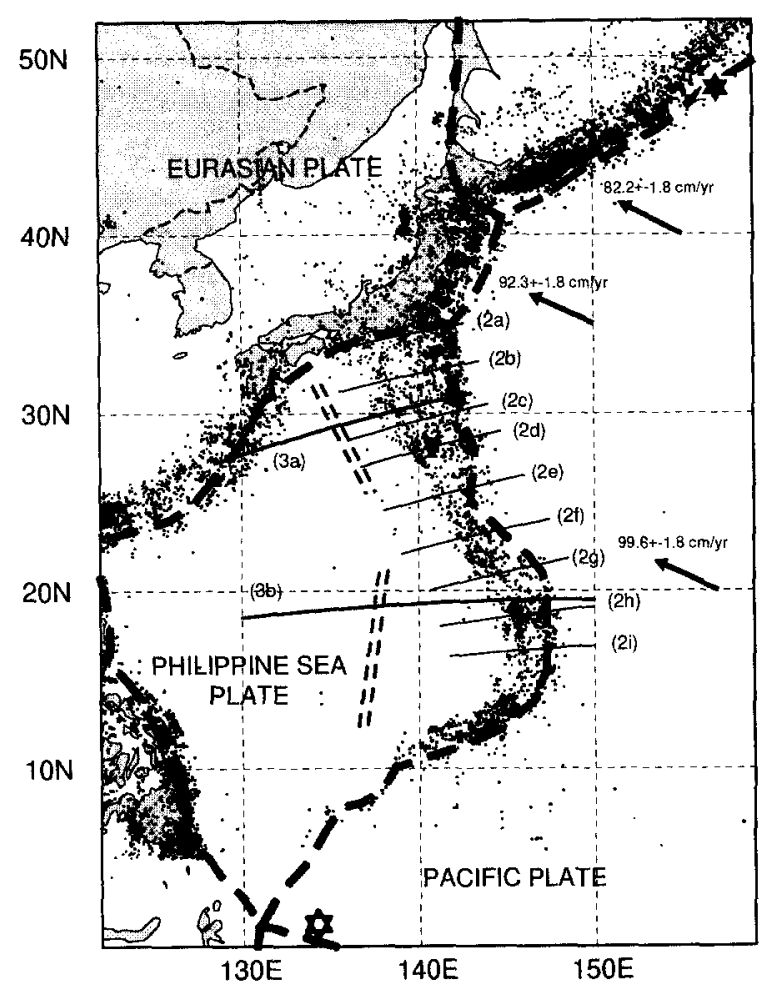

Fig. 1. Seismo-tectonic map of the northwestern Pacific region. Velocities of plate motion [12] are consistent with the NUVEL-1 model [50]. Epicentre locations for earthquakes larger than magnitude 4.5 on the Richter scale are from Engdahl, Van der Hilst, and Buland (in prep.). The solid star in the upper right-hand corner marks the location of the Euler pole for the clockwise rotation of the Philippine Sea plate relative to Eurasia; the open star in the lower left-hand corner marks the location of the Euler pole for the counterclockwise Pacific Philippine Sea plate motion [12]. The lines across the plate boundaries (depicted as dashed line) mark the strike lines of the cross sections shown in Fig. 2 (thin) and Fig. 3 (thick). predominance of down-dip compression. Together with the variation in shape of the seismic zone (Fig. 2) this indicates that at large depths subducted lithosphere below the Izu-Bonin arc is not continuous in a simple way to the slab below the Mariana arc. The age of subducting lithosphere is an important control in the subduction process [19], but the increase from about $135 \mathrm{Ma}$ at the northern Izu-Bonin trench to over $150 \mathrm{Ma}$ at the Mariana trench [20] is too small to explain the lateral variations in the Wadati-Benioff zones. We note, however, that significant changes in the age of subducted lithosphere have occurred during the post-Eocene evolution of the Philippine Sea plate [20] (see also below).

Fig. 3 shows a result of tomographic imaging of northwestern Pacific mantle structure. The images depict the velocity of compressional seismic waves relative to a radially stratified, global model of seismic velocities. The zones of higher-thanaverage seismic velocities in the direct vicinity of the inclined seismic zones depict slabs of subducted Pacific plate [7,8]. The slab below the Izu-Bonin arc is apparently deflected in the transition zone (Fig. 3a), which is in good agreement with results of other tomographic studies $[6,9]$ and with observed seismicity [7,14,21] (Fig. 2). Van der Hilst and co-workers [8] showed with a "checker board test" that the spatial resolution of lower mantle structure below the Izu-Bonin arc is good. For the specific "checker board" used this indicates that variations in seismic structure of wave lengths larger than about $200 \mathrm{~km}$, for instance a continuation of the slab into the lower mantle, would have been recognised by the inver-

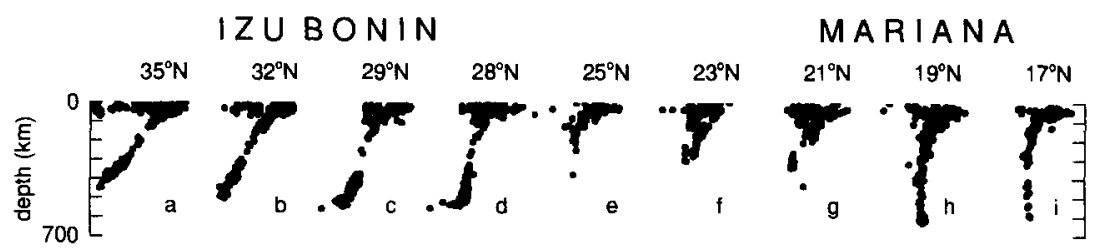

Fig. 2. Wadati-Benioff zones below Izu-Bonin and Mariana arcs. Hypocentre locations are from Engdahl, Van der Hilst, and Buland (in prep.). The lines of cross section are given in Fig. 1. Above each cross section the approximate latitude of the centre of the section lines is given. 
SEISMIC STRUCTURE BELOW IZU BONIN ARC $1345 \mathrm{~km}$
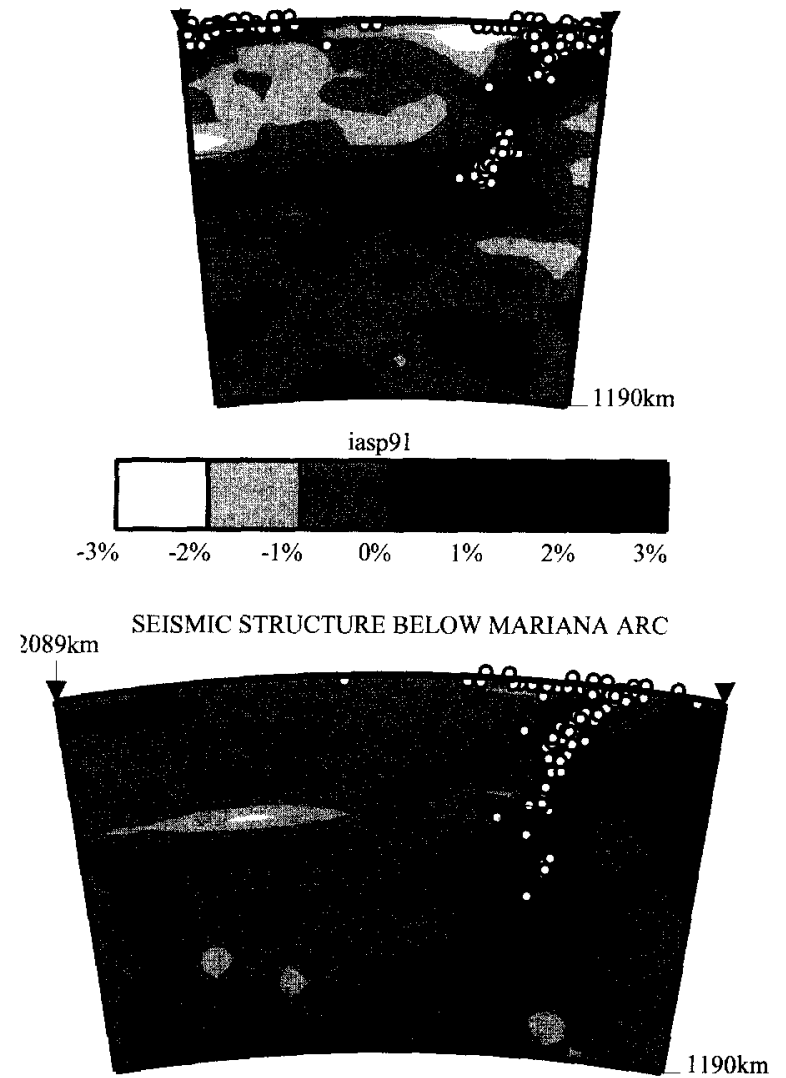

Fig. 3. Tomographic images from the study of Van der Hilst and co-workers [7,8]. They applied a linearized inversion technique [51] to travel time data of the direct $\mathrm{P}$ - and the surface reflected $\mathrm{pP}$-waves and solved for aspherical seismic structure of the Earth's mantle. The images depict seismic P-wave velocity relative to iasp91, a radially stratified model of seismic velocity [52]: the dark (light) grey represents regions where seismic velocity is higher (lower) than average. (a) Mantle section across the Izu-Bonin arc (top); and (b) mantle section across the Mariana arc (bottom). For locations see Fig. 1.

sion method used. It has been argued that a seismic discontinuity exists at an average depth of about $520 \mathrm{~km}$ [22]. This discontinuity is not present in the radially-stratified reference model. This could cause spurious structures in the images [23] but there are at least two reasons to believe that it can not explain the horizontal anomaly in Fig. 3b. First, the sub-horizontal anomaly is laterally restricted to certain regions
[7-9]. Second, the amplitude of the contrast in P-wave velocity is large (more than 6\%) and a global velocity increase of that magnitude would have been detected unequivocally in other seismological studies. Below the Mariana arc the slab-like high-velocity zone coincides with the almost vertical seismic zone in the upper mantle and transition zone (Fig. 2) and-in contrast to the Izu-Bonin slab-seems to continue to lower mantle depths (Fig. 3b). This is in accord with previous seismic studies $[24,25]$. Resolution tests indicate, however, that the seismic data used can not resolve the depth extent of the slab in the lower mantle [8].

\section{Inferences from fluid dynamical modelling and petrochemical studies}

The flux across the Earth's transition zone depends in a complex way on buoyancy forces due to variations in density, on thermodynamic properties of iso-chemical phase changes, on the depth dependence of viscosity and rheology in the transition zone [1-5,26], and-as will be argued below-on the relative motion of the lithospheric plates. Numerical fluid-dynamical experiments revealed that slab penetration and deflection, or, rather, deposition near the upper-lower mantle boundary, can coexist in the Earth's mantle, although they may be transient phenomena $[10,11,27,28]$. These models do not (yet) account for temperature dependent viscosity to simulate lithospheric plates and do not assess the effects of all buoyancy forces and can not readily explain the variations in slab morphology as discussed in the previous section.

Several investigators advocated that unobstructed slab penetration into the lower mantle is doubtful, because differential phase transformations in a compositionally stratified slab and the stability of garnet to large depths (possibly even to $800 \mathrm{~km}$ [Irifune, pers. commun., 1993]) can cause parts of the slab to become buoyant in the transition zone and uppermost lower mantle $[1,3,29,30]$. Others opposed this view and argued that this chemical buoyancy is overwhelmed by the integrated negative thermal buoyancy and 
does not prevent the penetration of slabs $[4,31]$. May the latter be correct for steep slabs [4,31], it does not necessarily hold for sub-horizontal slabs, or slabs with a small dip in the transition zone. Chemical buoyancy can then become significant for the dynamics [3,29] and trap the slab in a layer that is gravitationally stable on the time scales considered here ( $<50 \mathrm{Myr}$ ) [32]. We argue that there is not necessarily a causal relationship between chemical buoyancy and slab morphology. The initial deflection of a slab may well be caused by other factors such as an increase in viscosity and/or intrinsic density, perhaps in combination with the lateral displacement of downward flow in the upper mantle.

Laboratory experiments indicate that the dynamics and kinematics of lithospheric plates involved in the collision process can control the morphology of subducted slab [33, Griffiths and Hackney, pers. commun., 1993]. Kincaid and Olson [33] showed that if the lateral migration of the trench is sufficiently fast, subducted slab can be laid down above a flow-impeding boundary. In contrast, when the trench is stationary with respect to the lower mantle, subducted slab is likely to buckle and eventually penetrate the " $660 \mathrm{~km}$ " discontinuity provided an increase in intrinsic density is not too large $[27,33,34]$. In the following discussion of a plate-tectonic reconstruction we are, therefore, particularly interested in the amount and rate of lateral migration of the trenches and island arcs in the Izu-Bonin and Mariana plate boundary zone.

\section{Plate-tectonic reconstruction and the history of subduction}

The plate-tectonic history of the northwestern Pacific marginal basins is still disputed. For the Philippine Sea plate, reconstructions are complicated because of the absence of spreading ridges. Various evolution models have been proposed which can be classified in two groups. In one group, investigators have advocated that the location of the triple junction of the Japan, Ryukyu, and Izu-Bonin/Mariana trenches has been fixed relative to Japan and argued against a rotation of the Philippine Sea plate [35]. However, others advocated that the triple point of the Philippine, Pacific, and Eurasian plates migrated from the southwest to the northeast, accompanying a clockwise rotation of the Philippine Sea plate [36-38]. Results of a recent expedition of the Ocean Drilling Program (ODP) provides evidence in support of the latter group of models. Paleomagnetic data from islands and ODP sites in the Bonin-Mariana arc are indicative of a clockwise rotation by several tens of degrees since the Eocene, which can not be attributed to local deformation of the arc [39]. Models bearing on the clockwise rotation of the Philippine plate and the northeastward migration of the triple junction have in common that the trench retreat of the Izu-Bonin arc was larger than that of the Mariana arc during 30-17 Ma, although the amount of trench retreat may differ somewhat from model to model [36-39]. A detailed discussion of the plate reconstructions is beyond the scope of this paper.

The present discussion is illustrated by the reconstruction by Seno and Maruyama [37] and Seno [20] which belongs to the latter group of models (Figs. 4 and 5). This reconstruction bears on two episodes of oceanward trench migration, accompanied by back-arc spreading in the overriding PHS plate. After the change of Pacific plate motion in the Eocene and initiation of subduction the proto Izu-Bonin trench migrated northward until ca. $40 \mathrm{Ma}$ (Late Eocene), resulting in the back-arc opening of the West Philippine Sea basin (Figs. 4a,b). No significant further migration of the proto Izu-Bonin and Mariana trenches occurred between 40 and $30 \mathrm{Ma}$. Between about 30 and $17 \mathrm{Ma}$ (Late Oligocene-Middle Miocene) the proto Izu-Bonin trench migrated nearly $1000 \mathrm{~km}$ (ca. $75 \mathrm{~km} \mathrm{Myr}^{-1}$ ) but trench migration decreased southward to a maximum of $400 \mathrm{~km}$ for the Marianas (ca. $30 \mathrm{~km}$ $\mathrm{Myr}^{-1}$ ) (Figs. 4c,d and 5). The component of concurrent absolute motion of the Pacific plate perpendicular to the trench axis is estimated to be $850 \mathrm{~km} \mathrm{[40].} \mathrm{The} \mathrm{rapid} \mathrm{migration} \mathrm{of} \mathrm{the} \mathrm{Izu-}$ Bonin trench was accompanied by the back-arc opening of the Shikoku basin; the Parece Vela basin opened behind the retreating Mariana 

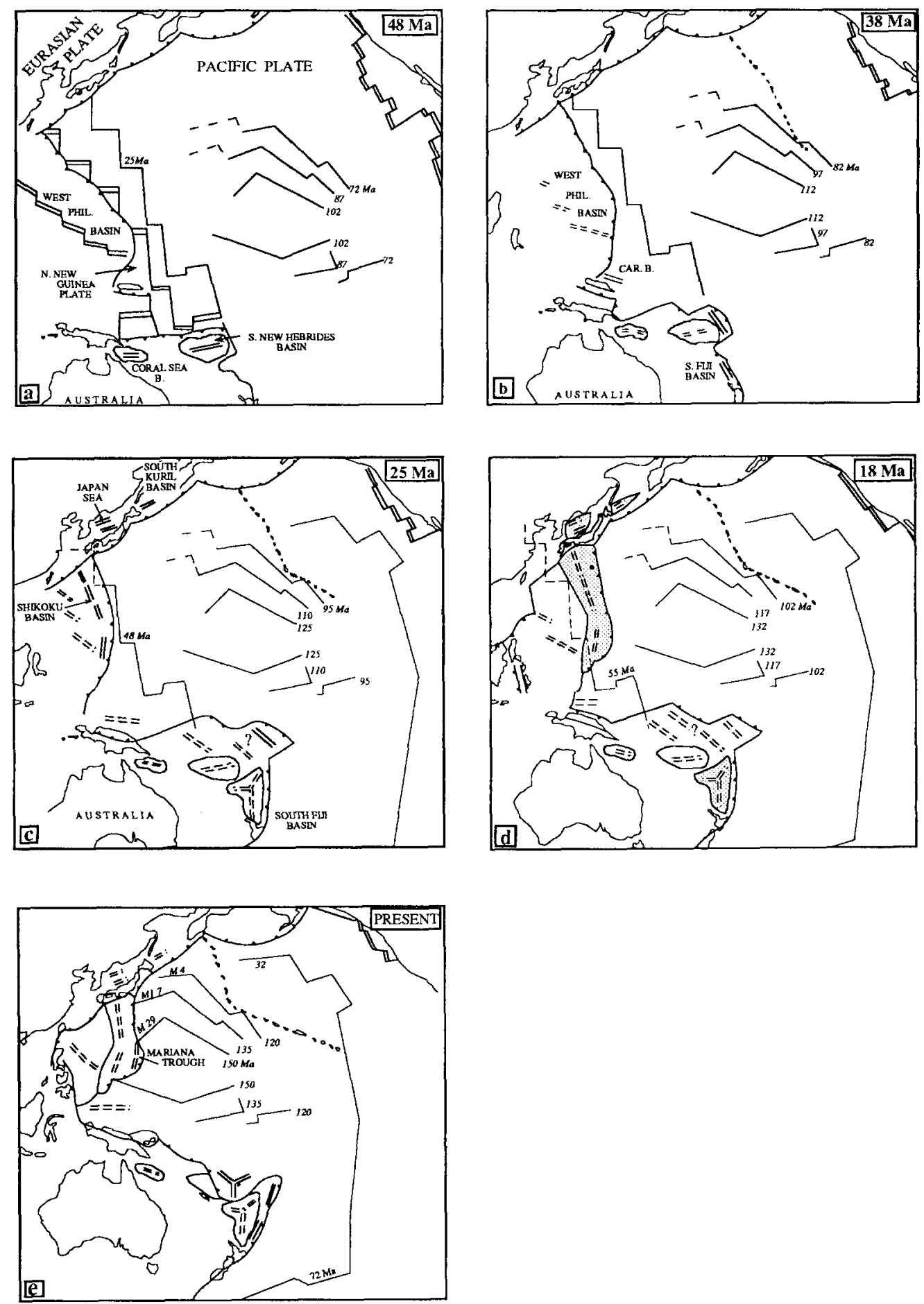
trench. The age of the subducted Pacific lithosphere increased dramatically (from about $50 \mathrm{Ma}$ to $110-130 \mathrm{Ma}$ ) around $25 \mathrm{Ma}$, which increased the negative buoyancy and the thermal inertia of the slabs and may have initially enhanced the trench migration and back arc spreading [20] (Figs. 4c,d).

Since the middle Miocene no significant oceanward trench migration occurred. In the Late Miocene-Pliocene, crust underlying the west Philippine basin had become old enough to cause subduction along the Philippine trench, and the motion of the PHS plate relative to Eurasia changed from northward to north-westward. Since this time, the location of the Euler pole for the motion between the PHS and Eurasian plates northeast of Japan (Fig. 1) resulted in a clockwise rotation of the PHS plate. This rotation causes the retreat of the PHS plate at the Mariana trench to be larger than at the Izu-Bonin trench. It has been argued [41,42] that this rotation, added to the post-Oligocene southward increase in age of subducted lithosphere [20] (Fig. 4d,e), caused the southward steepening of the IzuBonin/Mariana slab evident from seismicity (Fig. 2). Uyeda and Kanamori [15] and Le Pichon and Huchon [41] assumed that the Mariana slab was anchored in the lower mantle and explained the recent $(<6 \mathrm{Ma})$ opening of the Mariana trough by the landward retreat of the PHS plate. The mechanism for back-arc spreading behind the present-day Mariana arc is thus different from the processes that led to the opening of the older Shikoku and Parece-Vela basins. There is evidence for the northward propagation of back-arc spreading in the Mariana trough [43]. The small extension $(\sim 2-5 \mathrm{~km})$, the age of the rift $(\sim 2$ $\mathrm{Ma}$ ), and the accelerating subsidence in the Bonin back-arc indicate that the extension behind the Izu-Bonin arc is in an early stage of rifting [44].
RECONSTRUCTION AT 30 Ma AGO

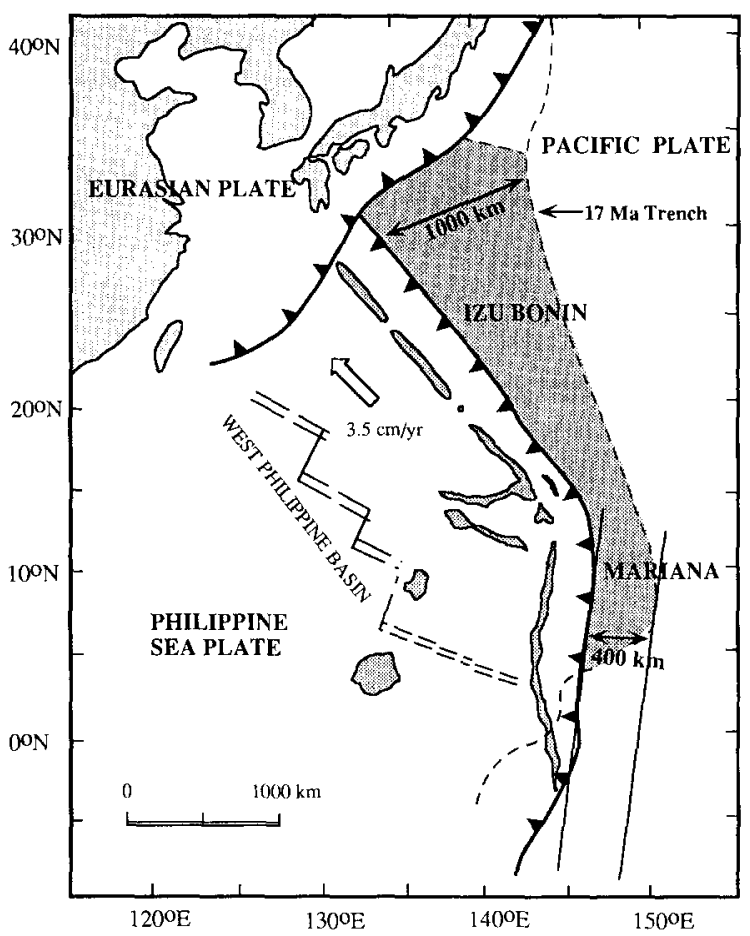

Fig. 5. Reconstruction of the Philippine Sea plate at $30 \mathrm{Ma}$ to illustrate the difference in the amount and rate of migration of the Izu-Bonin and Mariana trenches (after [37]). The trench at $17 \mathrm{Ma}$ is shown by the broken line. From the comparison of the trench lines at 30 and $17 \mathrm{Ma}$ the amount of trench migration is estimated to be up to $1000 \mathrm{~km}$ for the northern Izu-Bonin and at most $400 \mathrm{~km}$ at the centre of the Mariana trench. These figures are, however, model dependent [36-39] (see text).

\section{Evolution of slab morphology}

We summarise seismic and tectonic features pertaining to slab structure below the PHS plate in Figs. 5 and 6. In the following we speculate on how the tectonic history reviewed above (section 4) could have caused a mass distribution in the

\footnotetext{
Fig. 4. Plate-tectonic reconstructions of the West Pacific region to illustrate the age of the Pacific plate at various times and the evolution in time and space of the Izu-Bonin and Mariana convergent margins (after [20]). Isochrons of the Pacific plate are from ref. 40. (a) Reconstruction at $48 \mathrm{Ma}$. (Middle Eocene); (b) $38 \mathrm{Ma}$. (Late Eocene-Early Oligocene). The West Philippine basin has stopped opening; (c) $25 \mathrm{Ma}$. (Late Oligocene). Opening of the Shikoku-Parece Vela basins, the South Kuril basin, and the Japan Sea. Old oceanic lithosphere of the Pacific plate started to subduct beneath the Izu-Bonin and Mariana trenches; (d) 18 Ma. (Early Miocene). Back-arc basins of the western Pacific (shaded) stopped opening; (e) Present-day situation. The Philippine Sea plate is subducting beneath east Asia, producing the opening of the Mariana trough.
} 
Earth's transition zone that, with the inferences from petrochemical and fluid dynamical studies (section 3), can explain the seismic observations (section 2). We describe the evolution of the Izu-Bonin and Mariana subduction zones separately, but stress that the temporal changes of slab morphology may gradually propagate in space from south to north.

During the fast Oligocene-Middle Miocene (30-17 Ma) trench migration relatively young lithosphere subducted at the proto Izu-Bonin arc (Figs. 4 and 5). The combination of rapid trench migration and the initially low age and thermal inertia of subducted lithosphere could have resulted in a shallow subduction angle [19] below the northern part of the PHS plate and the laying down of slab material above the more viscous and perhaps slightly denser lower mantle [29,33] (Fig. $7 a)$. In contrast, the smaller Oligocene migration of the Mariana trench (Figs. 4 and 5) may have caused subducted lithosphere to accumulate in the transition zone in a relatively small area, without much, if any, laying down of the Mariana slab in a horizontal layer below the southern part of the PHS plate.

Since the Early Miocene, old Pacific lithosphere has been subducting below the Mariana arc [20] (Fig. 4) along a trajectory with a dip that became larger with progressing time [19,41,42]. The continued accumulation of subducted lithosphere with high thermal inertia in a laterally restricted area in the transition zone created conditions favourable for the penetration, or anchoring, of the slab in the lower mantle [33,34] (Fig. $7 b$ ). When the slab became anchored in the lower mantle and the landward retreat of the PHS plate continued, the Mariana trough opened by postMiocene back-arc spreading [37,41] (Fig. 7b). In the same time interval, the dip of the Izu-Bonin slab could have become larger because of the cessation of oceanward trench migration and the subsequent westward migration of the subduction hinge [42], more so in the south than in the north due to the clockwise rotation of the Philippine Sea plate and the southward increase in age of subducted lithosphere. Meanwhile, the horizontal

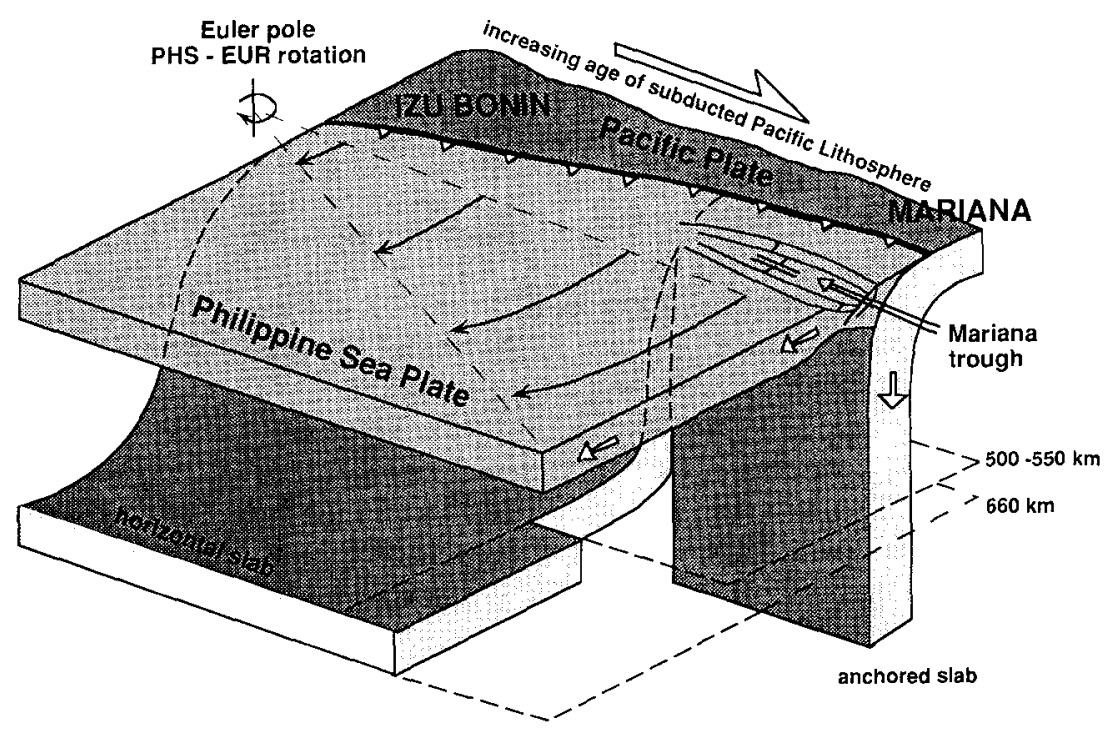

Fig. 6. Cartoon of the three-dimensional seismic structure below the Izu-Bonin and Mariana arcs and the Philippine Sea plate. This is an interpretation of the seismic images obtained for this region. Although slabs are presented as "plates" we assume that on geological time scales they do not behave as strong, elastic plates but as viscous fluids [28]. The lateral transition is represented as a tear but this is not resolved by the seismic data considered and-depending on rheology-can also be a flexural transition. The arrows indicate the clockwise rotation of the PHS plate and illustrate the difference in westward retreat of the overriding PHS plate between the Mariana and Bonin realms. 


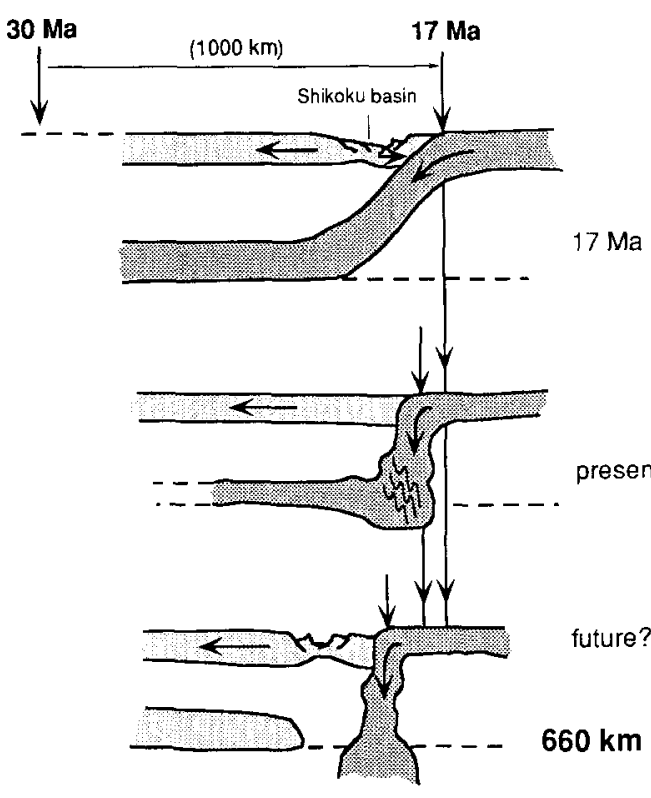

lzu Bonin

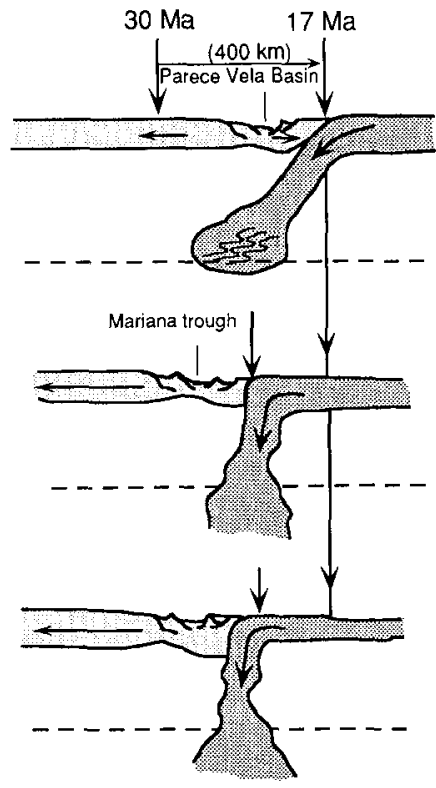

Mariana

Fig. 7. Cartoon of the evolution of slab morphology below the Izu-Bonin and Mariana convergent boundaries. This diagram is based on the interpretation of the seismic evidence [7,8,14], a plate tectonic reconstruction of the Philippine Sea region [20,37], scenarios for the southward steepening of the subducted slab [15,41,42], and dynamical $[10,11,33,34]$ and petrochemical models $[3,29,30]$. (a) Slab morphology after Late Oligocene to Middle Miocene trench migration (top). Below the northern part of the PHS plate subducted lithosphere is laid down in the transition zone as a result of the large oceanward migration of the Izu-Bonin trench. The amount and rate of trench migration decrease towards the south, and subducted lithosphere below the Mariana arc accumulated in a smaller region above the lower mantle. (b) Present-day slab morphology (middle). The Mariana trough opened when the slab became anchored in the lower mantle and the overriding PHS plate retreated westward, away from the trench. (c) Speculation on future slab morphology (bottom). The subduction below the future Izu-Bonin arc may be similar to the post-Miocene Mariana-type of subduction (middle). The continued westward retreat of the PHS plate may then result in more pronounced back-arc spreading behind the Izu-Bonin arc.

slab in the transition zone below the northern part of the PHS plate could have remained stable (Fig. 7b) in accord with petrochemical models $[1,29,30]$ and estimated survival times of a gravitationally stable layer [32], or with dynamical models if the difference in viscosity between upper and lower mantle is large enough [33]. Below the Izu-Bonin arc, the ongoing fast subduction of old lithosphere can cause the slab to buckle in the transition zone, which is apparent in the central part of the present-day Izu-Bonin subduction zone [14]. We speculate that eventually also the Izu-Bonin slab may penetrate into the lower mantle, similar to the post-Miocene Mariana type of subduction. In this scenario, the area below which slab penetration occurs expands to the north. If the landward retreat of the PHS plate continues, the penetration into the lower mantle of the Izu-Bonin slab is likely to be accompanied by the continued northward propagation of rifting in the Mariana trough and further back-arc spreading in the Izu-Bonin realm (Fig. 7c).

\section{Discussion and concluding remarks}

We used results from petrochemical and fluid dynamical studies in combination with a plausible plate-tectonic reconstruction for the area under study to understand better the seismic observations of lateral variation in slab morphology below the Izu-Bonin and Mariana arcs. Central in 
our discussion is the relationship between the amount and rate of trench migration and the deep structure of the slab. We argue that differences in migration of the Izu-Bonin and Mariana trenches could have caused the deposition of subducted slab in the transition zone below the former, but penetration into the lower mantle below the latter arc (Figs. 3, 6, and 7). In our explanation of the morphology of the Izu Bonin slab, "deflection" is not an adequate description of the predominant physical processes that cause the deep part of the Izu-Bonin slab to be subhorizontal, because we do not suggest a change of direction of flow from vertical to horizontal. Instead, we prefer to describe the process in terms of a deposition, or a laying down, of subducted slab above a more viscous and perhaps slightly denser lower mantle as a result of the lateral displacement of the trench.

Our discussion is illustrated with a particular plate-tectonic reconstruction, but our slab-evolution model is consistent with other reconstructions of the Philippine Sea region that are based on the northeastward migration of the triple junction of the Japan, Izu-Bonin, and Ryukyu trenches and the clock-wise rotation of the Philippine Sea plate, such as the model by Jolivet and co-workers [38] and those based on paleomagnetic data [39].

Further study is obviously required, but the relationship between oceanward trench migration and the lying of subducted slab near the boundary between the Earth's transition zone and the lower mantle seems to apply to other convergent plate boundary zones as well. The apparently deflected slabs in the northwest Pacific as inferred from tomographic imaging [7-9] are all located below marginal basins that formed by back-arc spreading in the Late Oligocene to Middle Miocene [20,38,45] (Fig. 4e): the sub-horizontal Izu-Bonin slab below the Shikoku basin, the Japan slab below the Japan Sea, and the southern part of the Kuril slab below the Kuril basin. The northern part of the Kuril slab seems to penetrate below the Kamchatka trench [7], which confirms the work by Jordan and co-workers [24]. This arc has a long history of subduction [46], but no evidence for oceanward migration of the Kam- chatka trench is reported. Preliminary results of tomographic imaging of southwestern Pacific mantle structure [Van der Hilst and Engdahl, in prep.] indicate that Pacific lithosphere subducted along the Tonga trench accumulates in a large, shallowly dipping body between 500 and $800 \mathrm{~km}$ in depth below the South Fiji basin. This basin formed by Oligocene $[20,38]$ back-arc spreading behind the clockwise migrating Tonga-Kermadec trench (Fig. 4e). The deep earthquakes (focal depth $>500 \mathrm{~km}$ ) below the Fiji basin [47] appear to be located in this apparently deflected slab.

Our evolutionary model is consistent with a range of physical mechanisms that impede but do not bar radial flow across the boundary between the transition zone and the lower mantle. The model bears on the transient nature of slab morphology and the flux across the boundary between transition zone and lower mantle. Apparent slab deflection and penetration can be juxtaposed in space and episodic in time (in accord with expectations from fluid dynamical experiments [Griffiths, personal commun., 1992]). From the tectonic reconstruction underlying our model [37] we infer that a transition to slab penetration can occur on a time scale of the order of $10 \mathrm{Myr}$, which is considerably faster than earlier estimates $[29,33]$ but in good agreement with recent models involving catastrophic mantle overturn [48].

The transient time depends on the tectonic evolution and is likely to vary between geographic regions. On time scales of the order of the transient time the flux between upper and lower mantle may be controlled in a complex, non-linear way by the motion of plates in combination with the depth dependence of rheology, intrinsic density, and viscosity, and the thermo-dynamics of the relevant phases changes, including those occurring in the compositionally stratified slab. The relatively fast, catastrophic "flushes" of upper mantle material into the lower mantle [48] may be related directly to plate-tectonic events. On time scales significantly larger than the transient time, the flux across the boundary between transition zone and lower mantle, and thus the large scale structure of mantle convection, depends more directly on the depth dependence of intrinsic density, the thermo-dynamics of the iso- 
chemical phase changes from upper to lower mantle mineral assemblages, and perhaps on rheology [26]. Most numerical and petrochemical models relate to this long-time average flux. In contrast, high-resolution seismic images are "snap-shots" of the transient regime and should be interpreted in the light of the tectonic evolution of a particular area.

We do not claim that the proposed evolutionary model is conclusive. The plate-tectonic history of the northwestern Pacific marginal basins is still disputed, although recent models concur on the aspects that are most important for our discussion, i.e. the trench migration and rotation of the PHS plate. We can only speculate, not prove, that the differences in subduction history between the Izu-Bonin and Mariana realms are large enough to explain the observed lateral variations in slab morphology. The relationships between tectonic evolution, in particular trench migration, and deep slab structure have to be quantified (see [49] and references therein for a promising approach) and established for other convergent margins as well. In addition, the time characteristics of the transients have to be investigated, either numerically or experimentally. Nevertheless, we argue that an explicit multi-disciplinary approach such as presented here can give insight into the complex processes involved in mantle dynamics. It can constrain the interpretation of seismic images and results of fluid dynamical experiments and helps to understand, for instance, why some subducted slabs penetrate into the lower mantle and why others don't. We hope that the ideas outlined in this paper will direct new research initiatives. A further understanding, and quantification, of the relationships between relative plate motions and deep slab behaviour could eventually enable us to use plate motion data explicitly to constrain the seismic inversions.

\section{Acknowledgments}

We enjoyed many interesting and instructive discussions on the topic of subduction, petrochemistry, and mantle dynamics with Ted Ring- wood, Bill McDonough, Ross Griffiths, and Geoff Davies. We thank them and Laurent Jolivet for their constructive reviews, and Satoru Honda, Dave Yuen, and Thorne Lay for providing us with preprints of their papers. We thank Clementine Krayshek for producing the final artwork of Figs. 4, 5, 6, and 7.

\section{References}

[1] D.L. Anderson and J.D. Bass, The transition region of the Earth's upper mantle, Nature 320, 321-328, 1986.

[2] P.G. Silver, W.W. Carlson and P. Olson, Deep slabs, geochemical heterogeneity, and the large-scale structure of mantle convection: investigations of an enduring paradox, Annu. Rev. Earth Planet. Sci. 16, 477-541, 1988.

P. Olson, P.G. Silver and W.W. Carlson, The large-scale structure of convection in the Earth's mantle, Nature $344,209-215,1990$.

[3] A.E. Ringwood, Phase transformations and their bearing on the constitution and dynamics of the mantle, Geochim. Cosmochim. Acta 55, 2083-2110, 1991.

[4] G.F. Davies and M.A. Richards, Mantle convection, J. Geol. 100, 151-206, 1992.

[5] T. Lay, The fate of descending slabs, Annu. Rev. Earth Planet. Sci., in press, 1993.

[6] H-.W. Zhou and R.W. Clayton, P and S wave travel-time inversions for subducting slab under the island arcs of the northwest Pacific, J. Geophys. Res. 95, 6829-6854, 1990.

[7] R.D. van der Hilst, E.R. Engdahl, W. Spakman and G. Nolet, Tomographic imaging of subducted lithosphere below northwest Pacific island arcs, Nature 353, 37-43, 1991.

[8] R.D. van der Hilst, E.R. Engdahl and W. Spakman, Tomographic inversion of $\mathbf{P}$ and $\mathrm{pP}$ data for aspherical structure below the northwest Pacific region, Geophys. J. Int. 105, 264-302, 1993.

[9] Y. Fukao, M. Obayashi, H. Inoue and M. Nenbai, Subducting slabs stagnant in the mantle transition zone, $J$ Geophys. Res. 97, 4809-4822, 1992.

[10] P. Machetel and P. Weber, Intermittent layered convection in a model mantle with an endothermic phase change at $670 \mathrm{~km}$, Nature 350, 55-57, 1991.

W.R. Peltier and L.P. Solheim, Mantle phase transitions and layered chaotic convection, Geophys. Res. Lett. 19, 321-324, 1992.

W. Zhao, D.A. Yuen and S. Honda, Multiple phase transitions and the style of mantle convection, Phys. Earth Planet. Inter. 72, 185-210, 1992.

[11] P.J. Tackley, D.J. Stevenson, G.A. Glatzmaier and G. Schubert, Effects of an endothermic phase transition at $670 \mathrm{~km}$ depth on spherical mantle convection, Nature $361,699-704,1993$. 
S. Honda, S. Balachander, D.A. Yuen and D. Reuteler, Three-dimensional mantle dynamics with an endothermic phase transition, Science 259, 1308-1311, 1993.

[12] T. Seno, S. Stein and A.E. Gripp, A model for the motion of the Philippine Sea plate consistent with NUVEL-1, J. Geophys. Res., in press, 1993.

[13] J.-M. Chiu, B.L. Isacks and R.K. Cardwell, 3-D configuration of subducted lithosphere in the western Pacific, Geophys. J. Inter. 106, 99-112, 1991.

[14] P.R. Lundgren and D. Giardini, Seismicity, shear-failure and modes of deformation in deep subduction zones, Phys. Earth Planet. Inter. 74, 63-74, 1992.

[15] H. Kanamori, Seismic and aseismic slip along subduction zones and their tectonic implications, in: Island arcs, deep-sea trenches, and back-arc basins, Maurice Ewing Series 1, M. Talwani and W. Pitman III, eds., pp. 163-174, 1977.

S. Uyeda and H. Kanamori, Back-arc opening and the mode of subduction, J. Geophys. Res. 84, 1049-1062, 1979 .

[16] L. Ruff and H. Kanamori, Seismic coupling and uncoupling at subduction zones, Tectonophysics 99, 99-117, 1983.

[17] T. Seno and T. Eguchi, Seismotectonics of the western Pacific region, in: Tectonics of the Western Pacific-Indonesian Region, S. Uyeda and T.W.C. Hilde, eds., Geodynamics Series GSA/AGU, 11, pp. 5-40, 1983.

[18] L. Astiz, T. Lay and H. Kanamori, Large intermediatedepth earthquakes and the subduction process, Phys. Earth Planet. Inter. 53, 80-166, 1988.

[19] N.J. Vlaar and M.J.R. Wortel, Lithospheric aging, instability, and subduction, Tectonophysics 32, 331-351, 1976. M.J.R. Wortel and N.J. Vlaar, Age-dependent subduction of oceanic lithosphere beneath western South America, Phys. Earth Planet. Inter. 17, 201-208, 1978.

P. Molnar and T. Atwater, Interarc spreading and cordilleran tectonics as alternates related to the age of subducted oceanic lithosphere, Earth Planet. Sci. Lett. $41,330-340,1978$.

[20] T. Seno, Age of subducting lithosphere and back-arc basin formation in the western Pacific since the Middle Tertiary, in: Formation of Active Ocean Margins, N. Nassau et al., eds., pp. 469-481, Terrapubl., Tokyo, 1985.

[21] K. Okino, M. Ando, S. Kaneshima and K. Hirahara, A horizontally lying slab, Geophys. Res. Lett. 16, 1059-1063, 1989.

[22] P.M. Shearer, Seismic imaging of upper mantle structure with new evidence for a $520-\mathrm{km}$ discontinuity, Nature 344, 121-126, 1990.

P.M. Shearer, Constraints on upper mantle discontinuities from observations of long-period reflected and converted phases, J. Geophys. Res. 96, 18146-18182, 1991. J. Revenaugh and T.H. Jordan, Mantle layering from ScS reverberations 2: the transition zone, J. Geophys. Res. 96, 19763-19780, 1991.

[23] R.D. van der Hilst and W. Spakman, Importance of the reference model in linearized tomographic imaging and images of subduction below the Caribbean plate, Geophys. Res. Lett. 16, 1093-1096, 1989.

[24] K.C. Creager and T.H. Jordan, Slab penetration into the lower mantle, J. Geophys. Res. 89, 3031-3049, 1984.

K.C. Creager and T.H. Jordan, Slab penetration into the lower mantle below the Mariana and other island arcs of the northwest Pacific, J. Geophys. Res. 91, 3573-3589, 1986.

[25] T. Kamiya, K. Miyatake and K. Hirahara, How deep can we see the high velocity anomalies beneath the Japan island arcs?, Geophys. Res. Lett. 15, 828-831, 1988.

[26] S.-.I. Karato, Z. Wang and K. Fujino, High creep strength and its bearing on the dynamics of the mantle, Nature, in press, 1993.

[27] M. Gurnis and B.H. Hager, Controls of the structure of subducted slabs, Nature 335, 317-321, 1988.

[28] W. Tao and R.J. O'Connell, Ablative subduction: a twosided alternative to the conventional subduction model, J. Geophys. Res. 97, 8877-8904, 1992.

[29] A.E. Ringwood and T. Irifune, Nature of the $650-\mathrm{km}$ seismic discontinuity: implications for mantle dynamics and differentiation, Nature 331, 131-136, 1988.

[30] D.L. Anderson, The upper mantle: Eclogite?, J. Geophys. Res. 84, 6297-6298, 1979.

[31] M.A. Richards and G.F. Davies, On the separation of relatively buoyant components from subducted lithosphere, Geophys. Res. Lett. 16, 831-834, 1989.

[32] U. Christensen, Is subducted lithosphere trapped at the 670-km discontinuity?, Nature 336, 462-463, 1989.

[33] C. Kincaid and P. Olson, An experimental study of subduction and slab migration, J. Geophys. Res. 92, 13832-13840, 1987.

[34] R.W. Griffiths and J.S. Turner, Viscous entrainment by sinking plumes, Earth Planet. Sci. Lett. 90, 467-477, 1988.

[35] Uyeda and Z. Ben-Avraham, Origin and development of the Philippine sea, Nature Phys. Sci. 240, 176-178, 1972. T. Matsuda, Collision of the Izu-Bonin arc with central Honshu: Cenozoic tectonics of the Fossa Magna, Japan, J. Phys. Earth 26, Suppl. 409-421, 1978.

S.D. Lewis, D.E. Hayes and C.L. Mrozowski, The origin of the west Philippine Basin by inter-arc spreading, in: Geology and tectonics of the Luzon-Marianas region, G.R. Balce and A.S. Zanoria, eds., pp. 31-51, 1982.

[36] D.E. Karig, Basin genesis in the Philippine Sea, Init. Report Deep Sea Drilling Project, U.S. Gov. Print. Off., Washington D.C. 31, 857-879, 1975.

[37] T. Seno and S. Maruyama, Paleogeographic reconstruction and origin of the Philippine Sea, Tectonophysics 102, 53-84, 1984.

[38] L. Jolivet, P. Huchon and C. Rangin, Tectonic setting of western Pacific marginal basins, Tectonophysics 160, 2347, 1989

[39] Koyama, S.M. Cisowski and P. Pezard, Paleomagnetic evidence for northward drift and clockwise rotation of 
the Izu-Bonin forearc since the early Oligocene, Scientific results "leg 126", Ocean Drilling program, Proc., pp. 353-370, 1992.

R.B. Haston and M. Fueller, Paleomagnetic data from the Philippine Sea plate and their tectonic significance, J. Geophys. Res. 96, 6073-6098, 1991.

[40] D.C. Engebretson, A. Cox, and R.G. Gordon, Relative motions between oceanic and continental plates in the Pacific basin, Spec. Pap. Geol. Soc. Am. 206, 59 pp., 1985.

[41] X. le Pichon and Ph. Huchon, Central Japan triple junction revisited, Tectonics 6, 35-45, 1987.

[42] R.L. Carlson and C.A. Mortera-Gutierrez, Subduction hinge migration along the Izu-Bonin-Mariana arc, Tectonophysics 181, 331-344, 1990.

[43] A. Saunders and J. Tarney, Back-arc basins, in: Oceanic Basalts, P.A. Floyd, ed., pp. 219-263, Blackie, Van Nostrand Reinhold, 1991.

[44] K. Fujioka, B. Taylor, and the "Leg 126 shipboard party", Arc volcanism and rifting, Nature 342, 18020, 1989.

B. Taylor, A. Klaus, G.R. Brown, G.F. Moore, Y. Okamura and F. Murakami, Structural development of Sumisu rift, Izu-Bonin arc, J. Geophys. Res. 96, 16113-16130, 1991.

[45] S. Maruyama and T. Seno, Orogeny and relative plate motions: example of the Japanese islands, Tectonophysics $127,305-329,1986$.

G. Kimura and K. Tamaki, Collision, rotation, and back- arc spreading in the region of the Okhotsk and Japan seas, Tectonics 5, 389-401, 1986.

[46] M.A. Richards and D.C. Engebretson, Large-scale mantle convection and the history of subduction, Nature 355 , 437-440, 1992.

[47] D. Giardini and J.H. Woodhouse, Deep seismicity and models of deformation in Tonga subduction zone, Nature 307, 505-509, 1984.

D. Giardini, Space-time distribution of deep seismic deformation in Tonga, Phys. Earth Planet. Inter. 74, $75-88,1992$.

[48] S.A. Weinstein, Catastrophic overturn of the Earth's mantle driven by multiple phase changes and internal heat generation, Geophys. Res. Lett. 20, 101-104, 1993.

[49] M.R. de Jonge, M.J.R. Wortel and W. Spakman, From reconstruction to upper mantle model: an application to the Alpine-Mediterranean region, Tectonophysics 223, 53-65, 1993.

[50] C.R. DeMets, R.G. Gordon, D. Argus and S. Stein, Current plate motions, Geophys. J. Inter. 101, 425-478, 1990.

[51] W. Spakman and G. Nolet, Imaging algorithms, accuracy, and resolution in delay time tomography, in: Mathematical Geophysics, N.J. Vlaar et al., eds., pp. 155-188, Reidel, Dordrecht, 1988.

[52] B.L.N. Kennett and E.R. Engdahl, Travel times for global earthquake location and phase identification, Geophys. J. Inter. 105, 429-465, 1991. 